\title{
HISTORY OF ULAMA LITERACY IN THE NEW ORDER - REFORMATION PERIOD: ULAMA OF AL-WASHLIYAH AND NAHDLATUL WATHAN
}

Abdul Karim Batubara, ${ }^{1}$ Rina Devianty ${ }^{2}$ and Azharuddin Mohd Dali

${ }^{(1,2)}$ UIN Sumatera Utara, Medan

${ }^{(3)}$ Universiti Malaya Kuala Lumpur, Malaysia

email: batubarakarim70@gmail.com,rinadevianty@gmail.com, azharud@um.edu.my

Abstract: This study aims to compare literacy produced by scholars from two major Islamic organizations in Indonesia, namely Al-Jami'atul Washliyah in North Sumatera and Nadhlatul Wathan in West Nusa Tenggara. A comparative study was conducted by looking at various books, kitab, and written works produced by the scholars of these two organizations. This is a field study using qualitative method. Sources of data in this study came from the results of observations, interviews, and literature study. The author's observations were conducted in Medan and Mataram as the main bases of these two organizations. Then the author interviewed the scholars who produced various scientific papers, especially those from the New Order and Reformation era. The author also conducted direct observations of books, kitab or other works of the scholars of these two organizations, journals, and other scientific works related to the research theme. As a result, scholars from these two organizations have produced various works, some of which were written during the New Order and Reformation eras. These works are closely related to the value of Islamic and nationality.

الملخص: تهدف هذه الدراسة إلى مقارنة الأدبيات المختلفة التي أنتجها باحثون من منظمتين

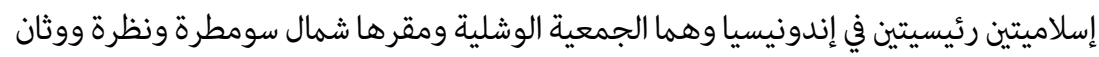

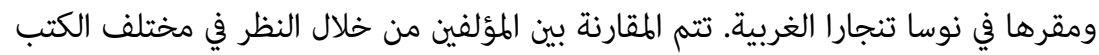
والكتب والأعمال المكتوبة التي أنتجها علماء هاتين المنظمتين. يتم تضمين هذا البحث فين في البحث البحث 
الميداني باستخدام طرق البحث النوعي في عملية الكتابة. جاءت مصادر البيانات في هذه الدراسة

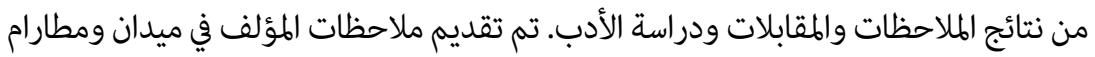

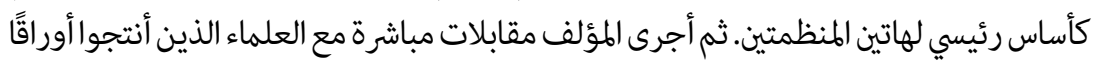

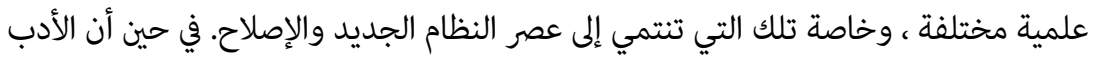

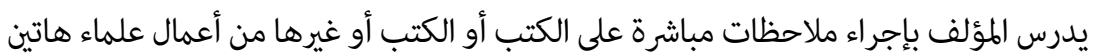

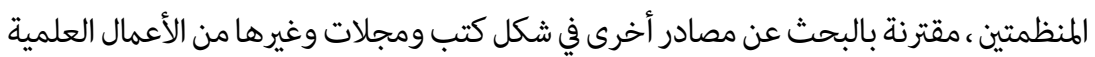

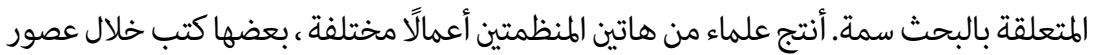

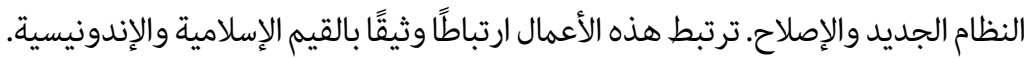

Abstrak: Penelitian ini bertujuan untuk membandingkan berbagai literasi yang dihasilkan oleh para ulama yang berasal dari dua organisasi keislaman besar yang ada di Indonesia, yaitu Al-Jami' atul Washliyah yang berpusat di Sumatera Utara dan Nadhlatul Wathan yang berpusat di Nusa Tenggara Barat. Perbandingan penulis lakukan dengan melihat berbagai buku, kitab, dan karya tulis yang dihasilkan oleh para ulama dari kedua organisasi ini. Penelitian ini termasuk ke dalam penelitian lapangan (field research) dengan menggunakan metode penelitian kualitatif di dalam proses penulisannya. Sumber data dalam penelitian ini berasal dari hasil observasi, wawancara, dan studi kepustakaan. Observasi penulis lakukan di Medan dan Mataram sebagai basis utama dari kedua organisasi ini. Kemudian wawancara penulis lakukan langsung dengan para ulama yang menghasilkan berbagai karya tulis ilmiah, terutama yang berasal dari masa Orde Baru dan Reformasi. Sementara studi kepustakaan penulis lakukan dengan melakukan pengamatan langsung terhadap kitab, buku, atau karya lainnya dari para ulama kedua organisasi ini, ditambah dengan pencarian sumber lainnya berupa buku, jurnal, serta karya ilmiah lainnya yang berkaitan dengan tema penelitian. Ulama-ulama yang berasal dari kedua organisasi ini telah menghasilkan berbagai karya, di antaranya ditulis pada masa Orde Baru dan Reformasi. Karyakarya tersebut sangat erat kaitannya dengan nilai-nilai keislaman serta keindonesiaan.

Keywords: literacy, ulama, works, al-Washliyah, Nahdhatul Wathan. 


\section{INTRODUCTION}

Literacy is the ability to read and write. The development of literacy becomes important to note because literacy is an initial ability that must be possessed by every individual to live a life in the future. Lack of interest in reading is a phenomenon that occurs in Indonesian society. Many Indonesian do not reading a lot, either reading literature or reading information. The quality of a nation is determined by its intelligence and knowledge, while intelligence and knowledge are produced by how much knowledge is gained, while knowledge is obtained through information obtained from oral and written. Thus, increasing literacy in a country is needed.

Most of the people in Indonesia are not aware of the urgency of literacy. Whereas the increase in understanding of literacy, as meant by the increase in reading or information gathering activities, is in the form of complex activities by moving a number of separate actions. What is meant by complex activities in reading includes understanding, imagining, counting, and observing and memorizing. ${ }^{1}$ In reading, there are internal factors that include intelligence, interests, attitudes, talents, motivation, and reading goals, while the external factors include the means of reading, form of reading texts, environmental factors, habits and traditions of reading. ${ }^{2}$

The development of Islam in Indonesia, of course, cannot be separated from the role of the ulama who spread the religion of Islam, up to remote areas of Indonesia. Surely they are $d a$ ' $i$ (preachers) who are ready and mature in terms of religious abilities. The ulama had previously studied in the Middle East, especially centered in Mecca and Medina, most of them returned to the archipelago, among others to teach religious knowledge and not a few of them who would later give birth to a paper, in the form of a book to be used as a reference in practice religious values. ${ }^{3}$

By writing, knowledge becomes eternal, can be learned for life. Ali ibn Abi Talib advised, "tie science by writing it down". Rasulullah

\footnotetext{
Ahmad Listiyanto and Rose Kusumaningratri, Speed Reading: Teknik dan Metode Membaca Cepat, Cetakan Pertama (Yogyakarta: A’ Plus Books, 2010), 14.

2 M. Quraish Shihab, Tafsir Al-Misbah: Pesan, Kesan Dan Keserasian alQuran, Vol. 15 (Jakarta: Lentera Hati, 2002), 4.

3 M. Fahim Tharaba and Mukhibat Mukhibat, "The Islamic Education Reform Early 20th Century," Al-Tahrir: Jurnal Pemikiran Islam 20, no. 1 (June 18, 2020): 124, https://doi.org/10.21154/altahrir.v20i1.
} 
Saw. said, "Whoever dies and his legacy in the form of ink and pen (written in a book) will go to heaven". And an Arab poet once said, "They died and left nothing they did to make funds as if their eternal legacy is only what they write with a pen" (Al-Jahidz). So be the scholars of the reader, the scholars of the writer, the literate ulama, the ulama who will enlighten the people. To be a competent human being, of course, an ulama must learn a lot of religious knowledge broadly and deeply plus the sciences The mentality as a learner will make him a literate human being, the basic thing is that a santri must have a lot of "Iqra" or reading, then he continues to deepen his knowledge, learn from the kyai, ajengan, ulama whose knowledge is higher than him. Basically, humans must be lifelong learners.

The ulama who have also devoted themselves to the pesantren have only been known as $d a^{\prime} i$ on the stand, only part of a narrow view. The roles of the ulama also educate and carry out knowledge transformation to students through oral recitation. Not a few of the ulama who are able to become Muslim scholars, through their writings that are very in-depth to a particular scientific discipline. The wealth of literature and intellectualism is evidenced by a large number of turats written by mushannif (authors) in pesantren backgrounds. These works are not only popular in Indonesia, but also to Arab lands. ${ }^{4}$ Although before experiencing the modern era and the acceleration of the global world towards access to information, ulama in Indonesia were able to produce works that are no less great than the Middle Eastern ulama. $^{5}$

Of course, more complex research is needed, especially looking at the ulama who were born in the Al-Washliyah organization in North Sumatera, and Nahdlatul Wathan in West Nusa Tenggara. To see the movement of the ulama in question, regarding the role of the literacy world in Indonesia, especially during the New Order and Reformation. In relation to the literacy movement, the ulema are actually already familiar with it, especially in relation to studying the yellow books

\footnotetext{
4 Iwan Kuswandi, "Tradisi Literasi Ulama Madura Abad ke- 19-20 M," in TRADISI LITERASI ULAMA MADURA ABAD 19-21 (SEMINAR NASIONAL GENDER \& BUDAYA MADURA III MADURA: PEREMPUAN, BUDAYA \& PERUBAHAN, Madura: LPPM Trunojoyo, 2019), 4.

5 Hajir Tajiri, "Integrasi Kognitif Dan Perilaku Dalam Pola Penanaman Disiplin Santri Di Pesantren Al- Basyariah Bandung," Al-Tahrir: Jurnal Pemikiran Islam 11, no. 2 (November 1, 2011): 416, https://doi.org/10.21154/al-tahrir.v11i2.42.
} 
written by the Sheikh and the ulama. In addition to studying the yellow books of ulama in Indonesia archipelago, various books were studied, ranging from monotheism, Sufism, fiqh, nahwu-sharaf science, the rules of reading the Qur'an and others.

The books studied by the santri are literacy works of Sheikh and great ulama. Physically, the ulama did not meet physically with the Sheikh and the ulama, but they could "meet", chat, and explore famous works that had hundreds of years old. The book that is read and studied by the ulama is a reflection of useful knowledge. ${ }^{6}$ Knowledge written will last a long time compared to science that is only spoken because it will be forgotten or forgotten. Therefore, the scholars besides reading and understanding the book, are also trained to be good at writing, both writing material, teaching material, and writing literature such as poetry as a medium to spread religious knowledge, moral messages, and humanitarian messages.

This research is included in field research because it studies intensively about the background of the current situation and social interactions, individuals, groups, institutions, and society. This research was conducted in two areas based on the mass of two organizations, Al-Washliyah in North Sumatera and Nahdlatul Wathan in West Nusa Tenggara, especially Lombok. The method used in this study is a qualitative research method. According to Bodgan and Taylor, qualitative methodology is a research procedure that produces descriptive data in the form of written or spoken words from people and observable behavior. ${ }^{7}$ This approach is directed at the background and the individual as a whole.

In collecting data sources, the authors use the techniques of observation, interviews, documentation, and literature study. The author's observations were conducted in the cities of Medan and Lombok as the main bases for these two organizations. The authors interviewed generations of Al-Washliyah and Nahdlatul Wathan scholars who lived and contributed during the New Order and Reformation era. Furthermore, the author observed on various books

6 Mahmud Arif, "ISLAM, KEARIFAN LOKAL, DAN KONTEKSTUALISASI PENDIDIKAN: Kelenturan, Signifikansi, Dan Implikasi Edukatifnya," Al-Tahrir: Jurnal Pemikiran Islam 15, no. 1 (August 25, 2015): 81, https://doi.org/10.21154/altahrir.v15i1.173.

7 Sugiyono, Metode Penelitian Kuantitatif, Kualitatif, Dan R\&D (Bandung: Alfabeta, 2011), 19. 
produced by the scholars of Al-Washliyah and Nahdlatul Wathan during the New Order and Reformation era. The author also collected documents and archives, in other literature that leads to scholarly literacy, especially scholars from Al-Washliyah and Nahdlatul Wathan.

\section{PRODUCTION OF AL-WASHLIYAH ULAMA WORKS IN NORTH SUMATERA}

Sheikh Muhammad Arsad Thariq Lubis lived in three periods, the Old Order and the New Order. He was arrested in the Dutch colonial period and the Old Order because of some of his work. During the New Order, his work was about the death guidelines according to the Qur'an and the Hadith. He also authored Imam Mahdi, the division of heirlooms, Muslim-Christian debates. He also wrote a book from the results of his debate with a Christian doctor in Medan on April 21, 1967, Fiqh, comparative religion which was his monumental work and fatwa which was a work written in the New Order era. Sheikh Al-Fadil Adnan Lubis is a famous Al-Washliyah's ulama. In addition, there are also Adnan Lubis (Medan) and Adnan Yahya Lubis (Seberlawan). Adnan Yahya Lubis wrote many books in the form of dictates, while Adnan Lubis's works were Tafsir Juz 'Amma dan Tafsir Yasin. The works of Ustadz Hamdan Abbas are still commonly found in the North Sumatera MUI library.

The writings of Sheikh Muhammad Arsyad Thalib Lubis were found in around 16 books (not including works written in addition to Arabic, Jawi and Indonesian). His writings can be grouped into three: (1) works written as madrasah dictates; (2) works written for dakwah to non-Muslims; and (3) works on religious themes in general. Among those written in the New Order era were:

1) Pedoman Mati Menurut Al-Qur'an dan Hadits

In this book talking about matters relating to death, this book is about 64 pages in Indonesian. Published by publisher Firma Islamiyah Medan (1972 AD).

2) Imam Mahdi

This book talks about Imam Mahdi, has 120 pages in Indonesian, published by the Firma Islamiyah Medan in 1387 H (1967 AD). 


\section{3) Ilmu Pembagian Pusaka}

This book explains the science of the distribution of inheritance which has 162 pages in Indonesian. This book was published by Publisher Firma Islamiyah Medan in 1400 H (1980 AD).

4) Debat Islam-Kristen Tentang Kitab Suci

This book talks about the author's debate with Christian leaders, dr. Sri Hardono dated April 21, 1967 AD on Friday night, about the scriptures at the author's house, Jalan Sei Kera, Medan. This book has 35 pages in Indonesian. This book is published by the Dakwah Council of the Great Management of Al-Jam'iyatul Washliyah.

5) Ilmu Fiqih

This book talks about complete fiqh. The reason for writing this book is to fulfill the requests of some people to write the Shafi'i school of figh. Therefore Muhammad Arsad Tariq Lubis wrote this book 233 pages in Indonesian. This book was published by Firma Islamiyah Medan in $1405 \mathrm{H}$ (1985) M.

6) Perbandingan Agama Kristen dan Islam

This book talks about the comparison of religion between Islam and Christianity. It Has of 478 pages in Indonesian language, published by New Malay Library Publisher Kuala Lumpur in 1982 M.

7) Fatwa (Beberapa Masalah)

This book talks about fatwas on 11 debated issues, such as gathering to recite the Qur'an, remembrance and wirid Yasin, the proposition of a Khutbah Hari Raya with two sermons, praying for 20 cycles of prayer, mentality of the dead, the living giving benefit to the dead, difference between witir, tahajjud and evening prayer, remembrance after prayer, reading the Qur'an without knowing its meaning, fasting with rukyah, gathering and eating at takziyah and other places. This book is 188 pages in Indonesian, published by Publisher Firma Islamiyah Medan (1982). This book was written on May 13, $1970 \mathrm{AD} / 1391 \mathrm{H}$.

There are several works of Sheikh al-Fadhil Adnan Lubis whose works are not much found except 2 books. But papers that entered the New Order era such as Tafsir Juz Amma, contained in this book about the interpretation of Juz Amma, it has342 pages in Indonesian. This book was published by Publisher Firma Islamiyah Medan (1967 AD). 
In addition there are several works of Sheikh Hamdan Abbas (1920-2002). He is an ulama from Kota Pinang, only found more or less the book:

1) Usul at-Tafsir (Arabic)

2) Fiqh Ibadah (Arabic)

3) Macam-Macam Benda yang Wajib Dizakati dan Nishabnya (with Prof. Dr. Abdullah Syah, published by MUI North Sumatera, 1986)

4) Muamalah Maliyah dalam Islam (published by MUI North Sumatera)

5) Perkembangan Akidah dalam Islam (published by MUI North Sumatera)

6) Sejarah Mazhab dan Perkembangannya (published by MUI North Sumatera, 1990)

In addition, Ustadz Abdul Majid Sirat, an Al-Washliyah's ulama. There are 4 of his works stored with his son, namely Ustadz Ulumuddin. His work is found in approximately 4 books:

1) Risalah Tauhid

2) Akhlak Anak Terhadap Orangtua

3) Al-Fiqh li al-Banin

4) Munazarah

Ustadz Lukman Sulaiman, also has many works such as his teacher, namely Sheikh Arsad Thariq Lubis. Ustadz Bahrum Jamil, a scholar who has a work that he poured into autobiography, and about the life history of Al-Washliyah ulama of East Sumatera (up to Sheikh Muhammad Arsad Thariq Lubis. Ustadz Ilhamuddin, his work was found there were 4, the ummah asked ulama to answer, this is his writings in the alert newspaper, the renewal of Shafi'i Islamic law, which is a dissertation, figh of worship (not yet published), and the translation of the sharah from Ummul Barohim.

Ustadz Bahrum Jamil (1924-1995) also has several works such as:

8 Ahmad Fauzi Ilyas, "Literasi Ulama Periode Orde Baru-Reformasi: Studi Komparatif Ulama Al Jam'iyatul Washliyah Di Sumatera Utara Dan Nahdhatul Wathan Nusa Tenggara Barat," in Literasi Ulama Periode Orde Baru-Reformasi: Studi Komparatif Ulama Al Jam'iyatul Washliyah Di Sumatera Utara Dan Nahdhatul Wathan Nusa Tenggara Barat (Focus Grup Discussion, Hotel Madani, Medan, 2019). 
1) Batu Demi Batu di Bawah Panas Yang Terik UISU Kami Dirikan (Medan, Ma'had Muallimin Al-Washliyah). This book is an autobiography. It states the author's relationship with the founders of Al-Washliyah. This book also contains a complete number of Al-Washliyah scholars from the 19th and early 20th centuries.

2) Pengantar Ilmu Politik

3) Hukum Perkawinan di Indonesia

Ustadz Ramli Abdul Wahid also has several works such as:

1) Pengantar Ilmu Hadits

2) Sejarah Hadis: Pertumbuhan, Perkembangan, Tokoh, dan Kitab Hadits

3) Telaah Terhadap Hadis-hadis Gugurnya Kewajiban Shalat Jumat dan zuhur bagi Orang Yang Menghadiri Shalat Ied

4) Telaah Terhadap Hadis-Hadis Tentang Hewan Sembelihan Non-Muslim

5) Ulumul Quran

6) Studi Ilmu Hadits

7) Kuliah Agama: Ilmiah Populer

8) Fiqh Sunnah Dalam Sorotan

9) Ilmu-Ilmu Hadits

10) Fiqh Ramadan

11) Hadits: Beberapa Aspek dari Ajaran Islam

12) Konsep Modal Dalam Al-Quran

13) Kamus Bahasa Melayu Asahan

14) Sejarah Pengkajian Hadits di Indonesia

15) Kupas Tuntas Ajaran Ahmadiyah

16) Peranan Islam Dalam Menghadapi Era Globalisasi Sekuler

17) Mengenal Islam: Akidah dan Syariah

Ustadzah Dr. Khadijah Hasanuddin's work on al-Washliyah which he composed Al-Jamiyah Al-Washliyah Api dalam Sekam, which is a dissertation. Ustadz Muhammad Razali's work combines five figures of Al-Washliyah ulama from Sheikh Hasan Maksum to Prof. Ramli. There are also many writings from several ulama published by Al-Ittihad recitation which are the works of Al-Washliyah ulama. Khadijah is the first female Doctor in the IAIN, her works such as $\mathrm{Al}$ Jam'iyatul Washliyah: Api dalam Sekam (dissertation). The content 
in this book talks about Al-Washliyah: from the sultanate of East Sumatera, the beginning of the founding and development of mass organizations, the history of ulama and founders of the organizations, preaching activities and activities in the Toba region. This book has 186 pages and is in Indonesian. This book was successfully completed in 1986 and published by Publisher Reader Bandung in 1988.

Ustadz Muhammad Nasir, Lc, MA has books such as Konkritisasi Islam dalam Kehidupan. This book talks about various themes about Islam, especially related to the issue of khilafiyah, such as the qabliyah on Friday, the number of rakaat (cycle) of praying, and others. Reasons for this writing as a rebuttal to the writings of Dr. Arifin Sakti in the Waspada newspaper is suing religious amaliyah. This book is about 232 pages in Indonesian. This book was published by Univa Press Medan in 2009.

Ustadz Dr. Ja'far, MA also has books such as:

1) Tradisi Intelektual Al Washliyah: Biografi Ulama Kharismatik dan Tradisi Keulamaan

2) Al Jam 'iyatul Washliyah: Potret Histori, Edukasi, dan Filosofi

3) Biografi Ketua Umum Pengurus Besar Al-Jamiyatul Washliyah

4) Ikatan Pelajar Al Washliyah

5) Biografi Pengurus dan Anggota Dewan Fatwa Al-Jam'iyatul Washliyah Periode 2015-2020

6) Al-Ittihadiyah: Delapan Darsawarsa Menerangi Nusantara

Ustadz Dr. Muhammad Rozali also has several books such as: Tradisi Keulamaan Al Jam 'iyatul Washliyah Sumatera Utara (LKiS, 2017). Lifted the gait of the five ulama: Sheikh Hasan Maksum, Sheikh Muhammad Arsyad Thalib Lubis, Ustad Nukman Sulaiman, Ustadz Dr. Lahmuddin Nasution, and Ustadz Prof. Dr. Ramli Abdul Wahid, M.A. Ustadz OK. Mas'ud, Ustadz Hafiz Yazid, Dr. Ardiansyah, M.A, Muhammad Arifin Jahari and Muhammad Tohir Ritonga whose work is a Kumpulan Kuliah Agama Islam Majelis Taklim Al-Ittihad (Collection of Islamic Studies in the Majelis Taklim Al-Ittihad). ${ }^{9}$

Nukman Sulaiman is also not much different from Muhammad Arsyad Thalib Lubis who is his teacher. He is an ulama who mastered religious discipline, it can be seen that he mastered several sciences, ranging from Arabic, Islamic history, interpretation, fiqh and ushul

9 Ibid. 
fiqh. He also opened the study of interpretation by reviewing the book of Tafsir al-Jalalain by Jalal ad-Din as-Suyuti and Jalal ad-Din alMahalli for thirteen years. He is indeed known to be proficient in the study of interpretation and also a hafidz of the Qur'an. This ability certainly supports his profession as a teacher, lecturer, bureaucrat and leader of religious social organizations such as Al-Jam'iyatul Washliyah. Part of those who say that the decline of al-Washliyah University was during the leadership of Nukman Sulaiman. ${ }^{10}$ In addition there are several works such as Tanya Jawab Masalah Hajji (Firma Islamiyah, 1980), Sendi Iman (Firma Islamiyah, 1977), Al-Quran Mukjizat yang Kekal (Singapura: Majlis Ulama, 1405 H), Apakah yang Diterima Nabi Ketika Mikraj, Ayat 10.000 Dinar, Bahaya Lidah, Kemuliaan Makkah, Manusia Empat Macam, Membangun Masjid, Nasehat Perkawinan, Pedoman Guru (Medan, Pustaka Univa, 1971), Perjumpaan Nabi Khidir dengan Nabi Musa dan Percakapan Antara Keduanya, Tunanetra Jangan Dihina, Ulul Albab, Wasiat Lukman Kepada Anaknya, Aqidah Islamiyah: PokokPokok Kepercayaan Dalam Islam (Medan, Pustaka Univa, 1972), Shalat dan Shalat Tarawieh (Medan, Yayasan Baitul Makmur dan MUI Sumut), and Suatu Tinjauan Hukum tentang Meminjamkan Rahim untuk Kandungan Bayi (pidato pengukuhan guru besar pada tahun 1987 di Univa).

\section{ISLAMIC AND INDONESIAN TOPICS IN AL-WASHLIYAH ULAMA LITERATURE IN THE NEW ORDER AND REFORMATION PERIOD}

Al-Washliyah ulama network in the country, the beginning of AlWashliyah establishment as an organization that is still too young, it is necessary to look for developer relations to be recognized and have a good method of preaching economic education and so on because Al-Washliyah is a community organization engaged in activities religiously. This is evidenced by the establishment of several madrasahs at that time which is spread in Medan and outside Medan. But still around East Sumatera. The forerunner of the Madrasah Tsanawiyah al-Kisuhaydi, then the Al-Washliyah madrasah stood.

10 Azhari Akmal Tarigan, Menjaga Tradisi Mengawal Medernitas Apresiasi Terhadap Pemikiran Dan Kiprah Lahmuddin Nasution (Bandung: Citapustaka Media Perintis, 2009), 34. 
This organization is also engaged in the social field of Al-Washliyah by establishing orphanages, one of which even exists in West Java. In addition, Al-Washliyah also built mosques and so on. The education curriculum at Al-Washliyah Islamic Boarding School is also trying to create Bank Pembangunan Rakyat (BPR), an Al-Washliyah People's Development Bank. However, at the beginning of its establishment, many Al-Washliyah figures entered politics such as Ustadz Hamzah. They are personally incorporated in the Masyumi Party. ${ }^{11}$

Historically Al-Jam'iyatul Washliyah ulama occupy an important position in the midst of the lives of the people of North Sumatera. This is because scholars do not only have authority in the religious field, but also in the fields of education, social, politics, and economics. The existence of several educational institutions both formal and informal is the contribution of ulama such as madrasah, mosques, and pesantren. Through educational institutions established and various books produced, scholars act as translators of doctrines of authoritative Islamic teachings, and at the same time as a process of transmitting religious values, particularly through education. ${ }^{12}$

The religious activities carried out by the Al-Jam'iyatul Washliyah ulama were carried out in an organized and various ways. Between an ulama and another has a different method. Nevertheless, they remain under one umbrella, the Al-Jam'iyatul Washliyah organization. These conditions continue to color the lives of the people and make the AlJam'iyatul Washliyah organization survive at nearly a century of age.

Efforts to improve the lives of people in North Sumatera never stop being done, the ulama tried to contribute ideas in both the political and economic fields. The purpose of politics is not to seek position and popularity, but purely to improve the social life of the Indonesian people and nation at that time. This is very much different from today's conditions, the leadership of Al-Jam'iyatul Washliyah is no longer dominated by the ulama who always think of the interests of society rather than personal life. ${ }^{13}$

11 Gonda Yumitro, Elfatih Abdullahi Abdelsalam, and Syaza Farhana Mohamad Shukri, "Proposed Development Models of Islamic Movements in Post Reformation Indonesia," Al-Tahrir: Jurnal Pemikiran Islam 20, no. 2 (November 3, 2020): 233.

12 Muhammad Rozali, Tradisi Keulamaan Al-Jam'iyatul Washliyah Sumatera Utara, cetakan pertama (Yogyakarta: LKiS, 2017), 196.

13 Ibid., 258. 
The role of al-Jam'iyatul Washliyah in improving the education system in North Sumatera even once had thousands of educational institutions scattered in this region. Not only limited to education, but Al-Jam'iyatul Washliyah also played his role in changing the lives of the community towards a better direction, namely the field of dakwah, social, political and economic. In the field of education, they collaborate with the management of madrasah diniyah. AlWashliyah's education is traditional and moderate. They study in places that already use the modern education system. It also discusses the Kitab Kuning, because the network built by Al-Washliyah with the Middle East, the Madrasah Al-Washliyah curriculum is more similar to the Al-Azhar curriculum. Al-Washliyah strongly safeguards his scholarship and his lessons in accordance with Al-Azhar's standards. They require students to memorize the Qur'an, some even memorize Alfiah Imam Malik.

In 1940, Al-Jam'iyatul Washliyah founded Madrasahal-Qismul Ali, Muhammad Arsyad Talib Lubis became the leader and teacher at the madrasah. He taught many fields such as fiqh, ushul fiqh, Sufism, rhetoric, adyan and interpretation. In addition, there are also big names of several other Hasan Maksum students who teach in this madrasah, such as Adnan Lubis as a hadith teacher, and Zainal Arifin Abbas teaches the history of Islam. Madrasah al-Qismul Ali, received attention from the wider community because this madrasah became a place for ulama to pour their knowledge, among them students who had studied at Hasan Maksum. ${ }^{14}$ After experiencing difficult times starting from the Dutch and Japanese occupations in 1941-1945, Muhammad Arsyad Thalib Lubis, always busy himself with developing the education of Al-Jam'iyatul Washliyah madrasah. After Indonesian Independence in 1945, he participated in filling independence through Al-Jam'iyatul Washliyah and several important positions in government, including as the Head of the Sharia Court and the Head of Religious Affairs in East Sumatera. In addition, he also channeled his knowledge in several universities in Sumatera. ${ }^{15}$

14 Dja'far Siddik and Rosnita Rosnita, "Gerakan Pendidikan Al-Washliyah Di Sumatera Utara," Ulumuna 18, no. 1 (November 8, 2017): 15-20, https://doi. org/10.20414/ujis.v18i1.143.

15 Ibid., 63. 
Al-Washliyah is an Islamic education reform organization, which has a high commitment to the development of the quality of education in Indonesia. In producing quality ulama, al-Washliyah has a madrasah that specifically educates future Al-Washliyah ulama. Madrasah Al-Qismul Aliy Al-Washliyah and Madrasah Aliyah Muallimin were founded by Al-Washliyah in order to produce future ulama. ${ }^{16}$ As an educational institution, Al-Jam'iyatul Washliyah has a way of giving birth to ulama. The method is a very important role in forming its own pattern for the next ulama, it also changes according to social conditions. According to Hafiz Yazid, in developing religious education, most ulama of Al-Jam'iyatul Washliyah used their respective methods. Al-Jam'iyatul Washliyah ulama have differences in teaching methods. The method obtained during the study with the teacher is reflected back to the students being taught. Example: Muhammad Arsyad Thalib Lubis who made a difference in delivering his lecture material in several universities in North Sumatera. He uses many classic books as his reference in teaching. This makes it appear different in the delivery of lecture material. In addition to using classical books composed by Shafi'i ulama, he also applied the contents of these books in real life before being taught to his students or students.

Some teaching methods used in every teaching and learning activity by the ulama of Al-Washliyah, namely: lectures, questions and answers, assignments, demonstrations, discussions, memorization. The lecture method is the longest teaching method, but the method is still often used. This method can be used anywhere and is followed by so many students. The religious education method carried out by the Al-Jam'iyatul Washliyah ulama is more similar to the educational method carried out by the Salaf pesantren in Indonesia. Some methods were adopted from the Middle East, but along with the changing times, these methods have gradually evolved. Thus, some ulama of Al-Jam'iyatul Washliyah also obtained and developed the educational method. These methods certainly do not represent the whole of the existing learning methods and have been experienced by Al-Jam'iyatul Washliyah ulama at home and abroad. ${ }^{17}$

16 Ibid., 72.

17 Rozali, Tradisi Keulamaan Al Jam'iyatul Washliyah Sumatera Utara, 95-97. 
In the field of dakwah, Al-Washliyah is one of the community organizations that can develop their dakwah in Sumatera, so that in 1937, MIAI appointed Al-Washliyah as an honorary member to develop dakwah in Sumatera. The importance of the position of dakwah in the body of Al-Jam'iyatul Washliyah, so that the dakwah must be formulated correctly in order to be carried out properly and precisely on its target. Dakwah can be interpreted as an effort to invite people towards understanding and practicing Islamic teachings in all aspects. The background of the establishment of Al-Jam'iyatul Washliyah in North Sumatera is to fill the world of Islamic education and the spread of Islam in North Sumatera. Al-Jam'iyatul Washliyah had carried out a movement in preaching long before the Indonesian people gained independence until now they still took part in programs aimed at providing enlightenment and knowledge to the public so as to open their eyes to goals that were in line with the aims of the Islamic religion. ${ }^{18}$

The teaching applied by Al-Washliyah is using the Kitab Kuning. However, only a few of the madrasah used the Kitab Kuning on primary (Ibtidaiyah), secondary (Tsanawiyah) or high education (Aliyah, Muallimin, Al-Qismul 'Ali). That is because of the lack of interest or ability of the scholars in maintaining this education informal education in the madrasah of Al-Jam'iyatul Washliyah, North Sumatera, coupled with the lack of scientific quality in Islamic studies. Then was born the idea to preserve the teaching of the Kitab Kuning outside of formal education. Reflecting on the religious tradition practiced both in the Middle East and in the Archipelago, some ulama of Al-Jam'iyatul Washliyah held talaqqī in their homes. At first, this study was impressed with the traditional teaching system of Islamic boarding schools in Java. Methods like this experience development with discussions to solve a problem that is developing. The emergence of some Al-Jam'iyatul Washliyah scholars' ideas to carry out studies of the Kitab Kuning on a regular basis is an attempt to maintain the tradition of clergy (ulama).

This study began with Kitab Kuning recitation that was formed to gather a number of Al-Jam'iyatul Washliyah ulama. In the beginning,

18 Syamsuddin Ali Nasution, “Al Jam'iyatul Washliyah Dan Perannya Dalam Dakwah Islamiyah Di Indonesia” (Disertasi, Kuala Lumpur, Universiti Malaya, 2001), 235 . 
this study tried to recruit Madrasah Al-Jam'iyatul Washliyah alumni who had studied in the Middle East. Aside from being a forum for gathering, the study was also expected to be a place to unite the thoughts of the Al-Jam'iyatul Washliyah ulama about Islam in North Sumatera. But this study had stopped because some of the study participants continued their education to Jakarta. In the end, we recite this study until Lahmuddin Nasution returns to Medan in 1998 after completing his education. Then the study was reopened at the Masjid Al-Washliyah in the Campus, Medan. However, due to several things among the initiators of this recitation, many had been unable to attend due to illness and death such as Usman Sarawi and Ustadz Jalaluddin who were occasionally present, eventually the study was continued by his successors such as Khaidir Abdul Wahab, Hafiz Yazid, Sarbaini Tanjung, and Muhammad Nasir. ${ }^{19}$

Al-Jam'iyatul Washliyah ulama' contribution to the world of education, of course, the conditions of struggle of each ulama also differed according to the conditions of the time. In the early days of the existence of Al-Jam'iyatul Washliyah, visible nuances of the clergy were so thick. This can be seen with the method of education which is more influenced by the nuances of the Middle East, which emphasizes the method of memorizing and using Arabic. But lately began to feel the looseness because the curriculum has been adjusted to the curriculum of the Ministry of Religion of the Republic of Indonesia. With this leeway, of course, it contributes to the continuation of the tradition of scholarship in Al-Jam'iyatul Washliyah. ${ }^{20}$

The importance of dakwah for the organization Al-Jam'iyatul Washliyah, so that the dakwah must be formulated correctly in order to be carried out properly and on target. If it is called preaching, it means calling, inviting or calling. It is fitting if called the preaching sentence then what is meant is Islamic propaganda. Thus preaching can be interpreted as an effort or activity to invite and call on people towards understanding and practicing the teachings of Islam in all

19 Ibid., 98-99.

20 Ahmad Hamim Azizy, Al-Jam'iyatul Washliyah dalam Kancah Politik Indonesia, ed. Taslim HM Yasin and Bachtiar Td Joesoef, Cetakan Pertama (Banda Aceh: Yayasan Pena, 2006), 117. 
aspects of both individual life and community life, in accordance with the understanding of the objectives of the Islamic religion. ${ }^{21}$

The Al-Washliyah ulama' network in Southeast Asia when Hamka became Chairman of the Indonesian Ulama Council, Sabah and Sarawak asked for ulama from Indonesia to teach in Sabah and Sarawak. When Hamka saw that the population of Malaysia was very similar to the population of Indonesia, Hamka felt that the Muhammadiyah people were not quite right when preaching in Malaysia, Hamka felt the most appropriate was the Al-Washliyah ulama, when viewed from the culture of Malaysian society, so sent 15 people to teach and preaching in Malaysia. ${ }^{22}$ After that 40 more people were sent to teach and preach in Malaysia until the relationship broke up and until now sent that has become a judge, official in Malaysia. The Middle East network, Al-Washliyah collaborated with Al-Azhar which was marked by the arrival of Sheikh Mahmud Syaltud and Muhammad Fahm to Univa. This means that the Al-Azhar chancellor came directly to Univa, Muallimin saw the curriculums and received recognition from the campus which was included as the oldest University in Egypt and he always became an institution that gave permission if there were Qur'an coming out of Mecca. ${ }^{23}$

\section{Production of Nahdlatul Wathan Ulama's Work}

Maulana Al-Sheikh TGKH. Muhammad Zainuddin Abdul Madjid as the heir the Prophets, besides delivering the dakwah bi al-hal wa bi al-lisan, also belongs to a prolific writer and author. His talent and ability as an author grew and developed since he was studying at the Madrasah Shaulatiyah in Mecca. However, due to the number and density of religious and social activities that must be filled, the opportunities and opportunities to reproduce writings appear to be very limited. Nevertheless, in the midst of the limited time, he still

${ }^{21}$ Nasution, “Al Jam'iyatul Washliyah Dan Perannya Dalam Dakwah Islamiyah Di Indonesia," 235.

${ }^{22}$ Moh Rifqi Khairul Umam, "ORGANIZATIONAL COMMITMENT IN THE WAQF ORGANIZATION OF MUHAMMADIYAH: A Perspective From Social Exchange Theory," Al-Tahrir: Jurnal Pemikiran Islam 20, no. 1 (May 11, 2020): 53, https://doi.org/10.21154/altahrir.v20i1.2006.

23 Fahrurrozi, Literasi Ulama Periode Orde Baru-Reformasi: Studi Komparatif Ulama Al Jam'iyatul Washliyah di Sumatera Utara dan Nahdhatul Wathan Nusa Tenggara Barat, Mataram, 2019. 
had time to compose several books, a collection of prayers, and songs of struggle in Arabic, Indonesian and Sasak language.

The several production works owned by him include: ${ }^{24}$

1) Hizb, is a collection of regular and chosen prayers with targeted goals (Afifudin Adnan). Hizb Nahdlatul Wathan and Hizb Nahdlatul Banat were born as a form of a request to Allah. To maintain the integrity of the NWDI and NBDI madrasah from the opponents of the madrasah system at the time, those who were envious, and even from the Japanese invaders who wanted to close the madrasah, thanks to God's help through the practice of Hizb Nahdlatul Wathan, the two madrasah were not dissolved by the Japanese. Meanwhile, around $60 \%$ of madrasah and religious schools in Indonesia were dissolved.

2) Al-Barzanji or Berzanji is a prayer, praise, and narration of the history of the Prophet Muhammad who is usually sung to the beat or tone. Contents of Berzanji tell about the life of the Prophet Muhammad, namely genealogy of his descendants, childhood, adolescence, adulthood until he was appointed as an apostle. It also tells of the noble qualities possessed by the Prophet Muhammad and various events to set an example for humanity.

3) Faraidh (knowledge of inheritance and procedures for calculation and distribution of inheritance) has a very important position in the context of the application of Islamic law in everyday life. First of all, this science is included in the series of Sharia sciences, namely the sciences applied by Allah. Even among the other Shariah sciences, this knowledge is the only one that is explained in detail in its provisions in the Qur'an.

4) Batu Ngompal is a book written in Sasak language, containing instructions or procedures for reading the Qur'an which is commonly referred to as the science of recitation. The book is for anyone who wants to deepen their understanding of the Qur'an.

5) Wasiat Renungan Masa Pengalaman Baru. Meditating Testament of Old and New Experiences. It is a book written in poetic form, containing advice and instructions for the struggle for the people

24 Ahsanul Khalik and Muhammad Zainuddin Abdul Madjid, eds., T.G.K.H. Muhammad Zainuddin Abdul Madjid, Pahlawan Kita, Ikhtiar Kita: Mengenang Satu Abad Satu Dekade Hamzanwadi, 1908-2018, Cetakan Pertama (Mataram: Dinas Sosial NTB, 2018). 
of Nahdlatul Wathan (NW). It is one of the regional literature, which deserves a place to be preserved. The height of the literary values in the testaments of the contemplation of a new period of experience can be seen from the structural elements. Whereas from the content of moral messages, in the form of advice, guidance, and good character, it can be seen in terms of the pragmatics of his poems.

Other works produced by him in Arabic among others: ${ }^{25}$

1) Risalah al-Tauhid

2) Sullam al-Hija Syarah Safinah al-Naja

3) Nahdlah al-Zainiah

4) At Tuhfah al-Amfenaniyah

5) Al Fawakih al-Nahdliyah

6) Mi'raj al-Shibyan ila Sama'i Ilm al-Bayan

7) Al-Nafahat 'ala al-Taqrirah al-Saniyah

8) Nail al-Anfal

9) Hizb Nahdlatul Wathan

10) Hizb Nahdlatul Banat

11) Tariqat Hizb Nahdlatul Wathan

12) Shalawat Nahdlatain

13) Shalawat Nahdlatul Wathan

14) Shalawat Miftah Bab Rahmah Allah

15) Shalawat al-Mab'uts Rahmah li al-'Alamin

There are at least Five Drivers of Literacy among NW ulama, especially by Maulana Al-Sheikh TGKH. Muhammad Zainuddin Abdul Madjid, namely:

First: Al-Fikrah al-Nahdhiyyah (Thought of the resurrection) which includes:

1) al-Nahdhah al-Tarbiyyah (revival of formal institutional education)

2) al-Nahdhah al-Ijtimâiyyah (social awakening)

3) al-Nahdlah al-Dakwatiyah (awakening of dakwah)

Second: Al-Fikrah al-Wathaniyyah National thinking; Indonesian thinking with the term Bilady Indunisiyya, Wathany. Mentioned in the songs by Maulana Al-Sheikh TGKH. Muhammad Zainuddin Abdul Madjid. Then the Sasak thinking, tribal primordialism to

25 Ibid. 
reinforce the identity and origin of the foundation of civilization such as Anti ya Fancur bilady, Ya fata Sasak bi Indonesia. His work has a meaning that is full of meaning, if we look at the brilliant thoughts of him about the ideas of nationalism and Islamic archipelago, as reflected in the expression of his wills verses: "Nahdlatul Wathan berjalan terus, Siang dan malam tidak terputus, Meskipun dahsyat gelombang arus, Dalam lindungan ilahi Quddus (Wasiat Renungan Massa, No. 23) Aduh sayang! Nahdlatul Wathan ciptaan ayahda, Ku amanatkan kepada anakda, Dipelihara dan terus dibina, Dan dikembangkan di Nusantara. (Wasiat. No. 39. h. 34) Aduh Sayang! Siarkan Hizib sampai merata, Agar banyaklah pendo'a kita, Mendo'a Negara, Nusa dan Bangsa, Mendo'a Islam se- Nusantara. (Wasiat. No. 52. h. 83). Aduh sayang! Ayahda tabligh di malam sunyi, Hadapi lautan, makhluk insani, Agar tersebar ajaran ilahi, di Nusantara dan Luar Negeri (Wasiat. No. 218) Aduh sayang! Duplikat Ngampel dan Kalijaga, Berlaku lebih tiga bulan nyata, Memancar sinar di Nusantara, Menghidupkan Iman bersinar Taqwa (Wasiat. No. 203)'”. As an indicator of how the conceptualization of his thought about Sasak can be seen from the string of verses in his will: Rasyid said one night, the Lombok foyer of Masjid al-Haram, since it was built to breathe Islam, by the son of Sulthanul Iman. That in Lombok before this, Understanding original animist teachings, Whenever visited by preachers, Finally born Sulthan Rinjani (Wasiat Renungan Masa).

Third: Al-Fikrah al-Siyasiyah or national political upheaval of the thought of independence, political thought of Pancasila democracy. This is seen in the dialectics of political dynamics of Maulana AlSheikh TGKH. Muhammad Zainuddin Abdul Madjid (1955-1997). National political thoughts and public politics are clearly stated in his great work, Wasiat Renungan Masa, printed 1980, as follows: Ajibnya terkadang di partai Islam, Berpura-pura membela Islam, Aktifkeliling siang dan malam, Membela diri melupakan Islam (Wasiat. 142. h. 55) Karena kafir tak pantai Bersyukur, Penuh khulaya' Hasad Takabbur, Tidak hiraukan teman dan Batur, Semau-maunya berpolitik Catur (Wasiat. No. 152). Janganlah nanda dibikin bubur, Oleh pemain politik catur, Diperalat untuk melawan batur, sehingga Ukhwah hancur dan lebur (Wasiat. No. 152.h.165) Banyak sekali berlidah Madu, Berhati Pahit Bagai Empedu, Berpolitik "Membelah Bambu", Tujuannya ummat jangan Bersatu. (Wasiat. No. 166. h.165), Politik 
satu ditambah satu, Ditambah satu sama dengan satu, Dilancarkan oleh golongan tertentu, Membela Nafsu membela Hantu (Wasiat. 168.h. 62).

Fourth: Al-Fikrah al-Diniyyah al-Islamiyyah includes the aqidah chosen by the Ahl al-Sunnah wa al-Jamaah, the Ash'ariyyah theology and the Sharia dimension chosen by the al-Imam al-Syafi'i school while the Tasawuf is chosen by the Nahdlatul Wathan is JunaidalBaghdady and al-Imam al-Ghazali. Thus the Nahdhatul Wathan actually operates in the realm of rabbaniyah, nabawiyyah, insaniyah, ummatiyah, kauniyah, alamiyah which are packaged in the frame of Washatiyah Islam (moderate).

Fifth: Al-Fikrah al-Diniyyah al-Wasathiyyah, Islamic moderation thoughts of Maulana Al-Sheikh TGKH. Muhammad Zainuddin Abdul Madjid.

As an ulama, Maulana Al-Sheikh TGKH. Muhammad Zainuddin Abdul Madjid focused himself on efforts to increase human piety to Allah Swt. Various literary works were written by him in the form of songs and poetry also contains a focus on religious invitations or advice. How can all people continue to learn, and increase devotion. In these religious advice songs, he still put NWDI, NBDI and NW as a joint forum to get closer to Allah.

A number of songs that contain religious advice include a song titled "Pacu Gamaq". This song contains an invitation to worship to increase devotion to Allah, there are no other virtues in this world that exceed the purpose of worshiping Allah, both property and throne. ${ }^{26}$

Some of the works produced by the scholars as well as ulama from Nahdlatul Wathan include TGH. Abdul Aziz Sukarnawadi who wrote a book with the TGKH. Muhammad Zainuddin Abdul Madjid Seputar Sanad Keilmuannya dan Pengijazahannya, Perisai Keaswajaan Nahdlatul Wathan Membedah 17 Literatur Anti Wahabi Rekomendasi Pendiri NW. Other works produced by TGH. Husnuddu'at who wrote a book titled Kesaktian Selawat Nabi.

${ }^{26}$ Yusuf Makmun et al., Dari Nahdlatul Wathan Untuk Indonesia: Perjuangan TGKH. Muhammad Zainuddin Abdul Madjid (1908-1997), cetakan kedua (Mataram: Dinas Sosial NTB, 2018). 


\section{ISLAMIC AND INDONESIAN TOPICS IN NAHDLATUL WATHAN ULAMA LITERATURE}

Islam and Nationality Insights are often seen as dichotomous, including in the context of Islam with an insight into Indonesian nationality. In fact, Islam centuries before the Proclamation of the Republic of Indonesia, August 17, 1945, had become an inseparable part of the Proclamation, which was in the reality of the religious, social, cultural, and political life of this country. Therefore, Islam and Nationalist Insight must not be dichotomous; but solely for practical purposes, that the two entities in the Indonesian context have been united and intersected. This unification is also obtained from the perspective of Maulana Al-Sheikh TGKH. Muhammad Zainuddin Abdul Madjid's thought and practice. How is the practice of integration of "IslamicIndonesian" which can further be referred to as "religious nationality thinking". 27

With knowledge brought directly from Makkah, Maulana AlSheikh TGKH. Muhammad Zainuddin Abdul Madjid understood in what way this Islamic religion was spread to the Sasak people. How to socialize it and what policies must be taken in order to strengthen the resilience of Islam in their eyes. He gradually incorporated Islamic values into the Sasak community, fusing Islamic values with community culture. These are strategic steps that are the capital or the engine driving Islam. ${ }^{28}$

In Wasiat Renungan Masa Pengalaman Baru, as moderation of Islam in the practice of Nahdlatul Wathan and his great citizens throughout the archipelago can be seen in five Islamic Moderation Pancalogi from the perspective of Maulana Al-Sheikh TGKH. Muhammad Zainuddin Abdul Madjid, among others: (1) Wa'yu alDiin (Religious Awareness and Spirit); (2) Wa'yu al-Ilmi (Awareness and Spirit of Science); (3) Wa'yu al-Jamâi (Organizational Awareness and Spirit); (4) Wa'yu al-Ijtimâiy (Community Awareness and Spirit);

27 Azyumardi Azra, "Islam Rahmatan Lil "Alamin Dan Wawasan Kebangsaan Perspektif TGKH. M. Zainuddin Abdul Madjid (1904-1997) Dan Nahdlatul Wathan,” in Islam Rahmatan Lil 'Alamin Dan Wawasan Kebangsaan Perspektif TGKH. M. Zainuddin Abdul Madjid (1904-1997) Dan Nahdlatul Wathan (Muktamar XIII Nahdlatul Wathan (NW) Pondok Pesantren Nurul Haramain, Narmada Lombok Barat, 2016).

28 Munawir Husni, Nahdlatul Wathan: restorasi Islam Indonesia Timur, cetakan kedua (Yogyakarta: Semesta Ilmu, 2018), 54. 
(5) Wa'yu al-Wathany wa al-Sya'by (National and state awareness and enthusiasm).

Islam in Indonesia has distinctive characteristics that distinguish it from Islam in other regions, especially Islam in the Middle East, which has influenced Islam in many parts of the world. The archipelago region has a number of uniqueness that is different from the uniqueness in other countries, starting from the geographical, socio-political uniqueness and traditions of civilization. ${ }^{29}$ Islam in the archipelago is the understanding and practice of Islam on the archipelago as a result of the dialectic between the Shari' a text and the reality and local culture. ${ }^{30}$ Meaning similarly that Islam in the Archipelago is a typical Islam of Indonesia, a combination of Islamic theological values with the values of local traditions, culture, customs in the country. ${ }^{31}$

This definition shows that substantially, Islam in Indonesia is an understanding of Islam and its implementation that takes place in the archipelago as a result of the synthesis between revelation and local culture, so that it has the nuances of local wisdom. In other words, Islam is characterized by Indonesia, or also as a result of the synthesis of theological values of Islam with the values of local traditions. It's just a region of motion in the first sense that calls the archipelago.

The thinking methodology of Maulana Al-Sheikh TGKH. Muhammad Zainuddin Abdul Madjid on the Sasak phenomenon is to reflect on the history of Sasak itself. It illustrates that he fully understands the historicity of Sasak and the typology of his people. From this study, he then formulated his thoughts on Sasak. According to him, the historical image of Sasak is a historical journey that shows the importance of the position of Islam in the life order of the Sasak people. At least it began after the collapse of animism and anthropomorphism (the imposition of human traits on animals or inanimate objects) in the Sasak community as a consequence of the

${ }^{29}$ Abdul Moqsith Ghozali, Metodologi Islam Nusantara (Bandung: Mizan, 2015), 115.

${ }^{30}$ Afifuddin Muhajir, "Meneguhkan Islam Nusantara Untuk Peradaban Indonesia Dan Dunia," Islam Nusantara Dari Ushul Fiqh Hingga Paham Kebangsaan, (Bandung: Mizan, 2015), 67.

31 Bizawie Zainul Milal, Islam Nusantara Sebagai Subjek Dalam Islam Studies Lintas Diskursus Dan Metodologi (Bandung: Mizan, 2015), 239. 
success of the Islamization process. So that no doubt, Islam becomes very attached in the lives of the Sasak people. ${ }^{32}$

Religion and art cannot be separated from the reality of human life. Art becomes a part of life that is united in every movement and emotion. The world's religions ranging from Judaism, Hinduism, Buddhism, Christianity, and Islam have strong artistic traditions. The scriptures they have must be read in a certain tone, not to mention the lyrics or the contents of the scriptures which contain high literary value because they come from God's revelation. The work of the ulama of Nahdlatul Wathan, which is very closely related to Islam and Indonesia, among others:

1) Pacu Gamaq song

a. Religion, this song contains an invitation to increase devotion to Allah, the religious messages shown by Maulana Al-Sheikh TGKH. Muhammad Zainuddin Abdul Madjid thick nuances of Sufism, the science of knowing how to purify the soul, clarify morals, develop physically and mentally and obtain eternal happiness.

b. Morality, the messages of morality are also rich in Maulana AlSheikh TGKH. Muhammad Zainuddin Abdul Madjid's work. How should be a human being to be a lot of themes delivered. Like the moral message delivered in verse Number 69 in "Wasiat Renungan Masa". This message is also found in the song "Sakit Jahil". The main thoughts are about the liver disease called ignorant pain. This type of pain has no cure except for studying religion. In this song, he also introduced two madrasahs which were established, namely NWDI and NBDI as a place to gain knowledge to be safe in the world and the hereafter.

c. Nationalism, in the context of a call for awareness of the Sasak people, Maulana Al-Sheikh TGKH. Muhammad Zainuddin Abdul Madjid also gave special emphasis about Sasak people in Lombok who are part of the Unitary State of the Republic of Indonesia. One song that shows a message like the one above is shown in the song "Ya Fata Sasak". He wrote this song estimated in the 1934s.

\footnotetext{
32 Focus Group Discussion.
} 
2) Ya Fata Sasak song

a. Hayya, collective calling, and togetherness. He understood the importance of collective work and togetherness. An organization will not succeed without collectivity (Jama'ah wa jam 'iyyah)

b. Nasyidana, our song. Song for us. Humming together. In the struggle of grief must be borne together. Happiness must be felt by everyone.

c. Ya Fata Sasak, oh young Sasak man. The call of the community and the call of primordialism as his identity as a Sasak people who have been tarnished with millions of experiences but do not forget where they came from.

d. Bi Indonesia, Sasak in Indonesia. Explain the existence of Sasak youth who continue to take part in Indonesia and even the Indonesia Archipelago, even the world. Mention of Sasak bi Indonesia. It is very possible for Sasak children to lead Indonesia or to affirm the commitment of entities and identities that must be able to compete.

e. Ballighil ayyyama wallayaaliya, Sasak youth must take a position as a messenger of the vision of religious and national vision who do not know day and night. Tireless and surrender.

f. Nahnu Ikhwanusshofa, we are a group of Ikhwanusshofa. Clever intellectuals who are educated and enlightened intellectuals. Our perception of the Sasak people with the Ikhwanusshofa means that we must think visionary and constructively for the delivery of the mission and vision towards an educated Indonesia. Describe the heroic figures of thinkers in order to become a guide and "role model for you Ya Fata Sasak".

g. Kulluna alal wafa, we are in the same loyalty and invaluable dedication. Loyalty and dedication are prerequisites for achieving the vision and mission of glory. There is no point in organizing if you are not loyal to the leadership of the organization. PB NW is the name. Don't overdo it to be number one. In Indonesia, if we are not in loyalty (Kulluna Alal Wafa). The point is we have to wafa over the leaders who are legalized in religion and state. To be smooth, we are heading towards $Y a$ Fata Sasak Bi Indonesia (Maulana's hope). 
h. Fastaiz bihizbina yahya, rise up through our organization so we are successful. Success with our organization Duhai Fata Sasak.

i. Lalalala nubaly lalala numaly, pledge and commitment to not give up and not to stop fighting.

\section{CONCLUSION}

The results of this research show that the ulama from Al-Washliyah and Nahdlatul Wathan were active in developing their organizations. The ulama from these two organizations have completed many levels of study by becoming Muslim scholars as well as educational figures who after receiving education, they returned to their homeland to develop education in their regions, specifically developing Islamic education. The ulama network originated from Al-Washliyah and Nahdlatul Wathan from the Middle East.

The Muslim scholars of Al-Washliyah and Nahdlatul Wathan were students from Mecca, Medina, and several African countries, like Egypt. In the New Order and the Reformation period both of these organizations gave birth to productive ulama who produced various kinds of works that were very identical to the face of Islam as well as Indonesian, the Al-Washliyah and Nahdlatul Wathan ulama have proven that an ulama must give enlightenment to the people, especially through a work that is produced both from the form of books, books, art, and various other works. Through the organization, the ulama devoted themselves to religion and nation.

\section{REFERENCES}

Arif, Mahmud. "ISLAM, KEARIFAN LOKAL, DAN KONTEKSTUALISASI PENDIDIKAN: Kelenturan, Signifikansi, Dan Implikasi Edukatifnya." Al-Tahrir: Jurnal Pemikiran Islam 15, no. 1 (August 25, 2015): 67. https://doi. org/10.21154/al-tahrir.v15i1.173.

Azizy, Ahmad Hamim. Al-Jam'iyatul Washliyah dalam Kancah Politik Indonesia. Edited by Taslim HM Yasin and Bachtiar Td Joesoef. cetakan pertama. Banda Aceh: Yayasan Pena, 2006. 
Azra, Azyumardi. "Islam Rahmatan Lil 'Alamin Dan Wawasan Kebangsaan Perspektif TGKH. M. Zainuddin Abdul Madjid (1904-1997) Dan Nahdlatul Wathan." In Islam Rahmatan Lil 'Alamin Dan Wawasan Kebangsaan Perspektif TGKH. M. Zainuddin Abdul Madjid (1904-1997) Dan Nahdlatul Wathan. Narmada Lombok Barat, 2016.

Fahrurrozi. Literasi Ulama Periode Orde Baru-Reformasi: Studi Komparatif Ulama Al Jam'iyatul Washliyah di Sumatera Utara dan Nahdhatul Wathan Nusa Tenggara Barat. Mataram, 2019.

Ghozali, Abdul Moqsith. Metodologi Islam Nusantara. Bandung: Mizan, 2015.

Husni, Munawir. Nahdlatul Wathan: restorasi Islam Indonesia Timur. Cetakan kedua. Yogyakarta: Semesta Ilmu, 2018.

Ilyas, Ahmad Fauzi. 'Literasi Ulama Periode Orde Baru-Reformasi: Studi Komparatif Ulama Al Jam'iyatul Washliyah Di Sumatera Utara Dan Nahdhatul Wathan Nusa Tenggara Barat.” In Literasi Ulama Periode Orde Baru-Reformasi: Studi Komparatif Ulama Al Jam'iyatul Washliyah Di Sumatera Utara Dan Nahdhatul Wathan Nusa Tenggara Barat. Hotel Madani, Medan, 2019.

Khalik, Ahsanul, and Muhammad Zainuddin Abdul Madjid, eds. T.G.K.H. Muhammad Zainuddin Abdul Madjid, Pahlawan Kita, Ikhtiar Kita: Mengenang Satu Abad Satu Dekade Hamzanwadi, 1908-2018. Cetakan pertama. Mataram: Dinas Sosial NTB, 2018.

Kuswandi, Iwan. "Tradisi Literasi Ulama Madura Abad ke- 19-20 M.” In TRADISI LITERASI ULAMA MADURA ABAD 19-21, 4. Madura: LPPM Trunojoyo, 2019.

Listiyanto, Ahmad, and Rose Kusumaningratri. Speed Reading: Teknik Dan Metode Membaca Cepat. Cetakan pertama. Yogyakarta: A' Plus Books, 2010.

Makmun, Yusuf, Abdul Fattah, Salimul Jihad, Agil Al Idrus, and Hirjan Nahdi. Dari Nahdlatul Wathan Untuk Indonesia: Perjuangan TGKH. Muhammad Zainuddin Abdul Madjid (1908-1997). Cetakan kedua. Mataram: Dinas Sosial NTB, 2018. 
Milal, Bizawie Zainul. Islam Nusantara Sebagai Subjek Dalam Islam Studies Lintas Diskursus Dan Metodologi. Bandung: Mizan, 2015.

Muhajir, Afifuddin. "Meneguhkan Islam Nusantara Untuk Peradaban Indonesia Dan Dunia." Islam Nusantara Dari Ushul Fiqh Hingga Paham Kebangsaan, Bandung: Mizan, 2015.

Nasution, Syamsuddin Ali. “Al Jam'iyatul Washliyah Dan Perannya Dalam Dakwah Islamiyah Di Indonesia." Doktoral Thesis, Universiti Malaya, 2001.

Rozali, Muhammad. Tradisi Keulamaan Al Jam'iyatul Washliyah Sumatera Utara. Cetakan pertama. Yogyakarta: LKiS, 2017.

Shihab, M. Quraish. Tafsir Al-Misbah: Pesan, Kesan Dan Keserasian al-Quran. Vol. 15. Jakarta: Lentera Hati, 2002.

Siddik, Dja'far, and Rosnita Rosnita. "Gerakan Pendidikan AlWashliyah Di Sumatera Utara." Ulumuna 18, no. 1 (November 8, 2017): 59-80. https://doi.org/10.20414/ujis.v18i1.143.

Sugiyono. Metode Penelitian Kuantitatif, Kualitatif, Dan R\&D. Bandung: Alfabeta, 2011.

Tajiri, Hajir. "Integrasi KognitifDan Perilaku Dalam Pola Penanaman Disiplin Santri Di Pesantren Al- Basyariah Bandung." AlTahrir: Jurnal Pemikiran Islam 11, no. 2 (November 1, 2011): 415. https://doi.org/10.21154/al-tahrir.v11i2.42.

Tarigan, Azhari Akmal. Menjaga Tradisi Mengawal Medernitas Apresiasi Terhadap Pemikiran Dan Kiprah Lahmuddin Nasution. Bandung: Citapustaka Media Perintis, 2009.

Tharaba, M. Fahim, and Mukhibat Mukhibat. "The Islamic Education Reform Early 20th Century." Al-Tahrir: Jurnal Pemikiran Islam 20, no. 1 (June 18, 2020): 121-41. https://doi. org/10.21154/altahrir.v20i1.2008.

Umam, Moh Rifqi Khairul. "ORGANIZATIONAL COMMITMENT IN THE WAQF ORGANIZATION OF MUHAMMADIYAH: A Perspective From Social Exchange Theory." Al-Tahrir: Jurnal Pemikiran Islam 20, no. 1 (May 11, 2020): 51-73. https://doi. org/10.21154/altahrir.v20i1.2006. 
Yumitro, Gonda, Elfatih Abdullahi Abdelsalam, and Syaza Farhana Mohamad Shukri. "Proposed Development Models of Islamic Movements in Post Reformation Indonesia." Al-Tahrir: Jurnal Pemikiran Islam 20, no. 2 (November 3, 2020): 231-50. 